\title{
Metal Uptake in Reeds from 'Flowback' Fluids
}

\author{
Bobbie Perry ${ }^{1}$, Canaan Sutton ${ }^{1}$, Lin Guo ${ }^{1 *}$, \\ Xingzhong Yan ${ }^{2}$, Junxing Yang ${ }^{3}$ \\ ${ }^{1}$ Department of Biological and Environmental Sciences, Texas A\&M University-Commerce, TX, USA, 75428 \\ ${ }^{2}$ Department of Chemistry, Texas A\&M University-Commerce, TX, USA, 75428 \\ ${ }^{3}$ Center for Environmental Remediation, Institute of Geographic Sciences and Natural Resources Research, \\ Chinese Academy of Sciences, Beijing, PR China, 100101
}

Received: 18 March 2017

Accepted: 15 May 2017

\begin{abstract}
Flowback fluids from the hydraulic fracturing process that contain high levels of metals may pose environmental risks. This laboratory study investigated the remediation potential of Phragmites australis to sequester $\mathrm{Ba}$ and $\mathrm{Sr}$ from flowback liquids. The results indicated that reeds can uptake different concentrations of $\mathrm{Ba}$ and $\mathrm{Sr}$ from solutions. Roots were the main tissues for metal storage, with $12.26 \pm 0.58 \mathrm{mg} / \mathrm{g} \mathrm{Ba}$ and $2.92 \pm 0.12 \mathrm{mg} / \mathrm{g} \mathrm{Sr}$ sequestered in roots from solutions that contained $80 \mathrm{mg} / \mathrm{L} \mathrm{Ba}$ and $20 \mathrm{mg} / \mathrm{L} \mathrm{Sr}$. The more metals in solutions, the more metals that entered the biomass. Reed, which possesses strong adaptability to different conditions and environments, is a good candidate to clean heavy metal-contaminated water or soil via phytoremediation. Field research on metal accumulation in reeds cultured in flowback liquids is needed to further prove its potential to in situ remediation of a heavy metal-contaminated environment.
\end{abstract}

Keywords: reeds, phytoremediation, barium, strontium

\section{Introduction}

Hydraulic fracturing is currently one of the primary techniques for extracting gas and oil for energy production across the United States. During the hydraulic fracturing process, large amounts of water, sands, and chemicals are injected underground to fracture rocks and release gas or oil. According to future energy forecasts, energy production from hydraulic fracturing will double by 2035 [1]. The process involves utilizing millions of gallons of fresh water each year and managing high concentrations of toxic elements released in flowback water [2]. "Flowback" fluids produced during the hydrofracturing process currently pose potential environ-

*e-mail: Lin.Guo@tamuc.edu mental risks [1,3]. Flowback fluids are water that return to the surface when the hydraulic fracturing process is done [1]. High concentrations of toxic elements such as barium (50-9,000 ppm) and strontium (50-6,000 ppm) are reported in most flowback water [1, 4-5].

Currently, treating and removing metals in flowback fluids is mainly done by utilizing centralized wastewater treatment. Centralized wastewater treatment facilities include basic separation techniques such as precipitation for disposal of oil and metals to advanced treatments such as membrane bioreactor and reverse osmosis for removal of total dissolved solids (TDS), dissolved organics, and boron [2]. The effluents from centralized wastewater treatment facilities mainly are for reuse in fracturing activity, and/or direct discharge to surface water with a National Pollution Discharge Elimination System [2]. Although reuse minimizes the wastewater management procedures in the 
short term, it may result in the accumulation of dissolved solids [2]. Eventually, wastewater reused more than once will still need to be disposed of, either through centralized wastewater treatment or injection [2]. Injection wells are regulated under the Safe Drinking Water Act. They are designed and constructed to inject fluids to authorized zones that avoid contamination of underground sources of drinking water [6]. However, these treatment methods are costly, and have high energy and chemical demands. Additionally, centralized wastewater treatment cannot effectively remove all of the toxic chemicals. High levels of toxic metals and radioactivity have been reported in drinking water intake streams and in rivers near wastewater treatment outflows [7]. For example, high levels of toxic metals (248.6-1084 mg/L Sr, 95-140 mg/L Ba), and radioactive chemicals (benzene and toluene) have been reported in effluent discharge from treatment sites [7].

A promising method for removing metals from surface water contaminated by spilled flowback fluids or rivers near centralized wastewater treatment outflows is plantbased technologies known as phytoremediation. As a clean, simple, low-cost, non-environmentally disruptive green technology, phytoremediation has attracted more and more attention from the public [8]. Phytoremediation is the use of plants to restore a contaminated environment [9]. Plant species that can survive under atrocious conditions (i.e., low $\mathrm{pH}$, low levels of nutrients, and high metal concentrations) such as common reed (Phragmites australis) and cattail (Typha latifolia) are commonly used in wetlands for wastewater treatment [10-11]. Phytoremediation has also been reported to be a potential way to remove metals from acid mine drainage (AMD)-contaminated water or soil [12]. However, most of the studies related to phytoremediation have focused on the removal of organic contaminants or single metals from water or soil. Very little is known about the effect of phytoremediation on removing multiple toxic metals from contaminated water. In addition, studies on phytoremediation of hydraulic fracturing fluid-contaminated water have not been widely reported. This project studied the potential of plants to uptake metals from hydraulic fracturing-contaminated solutions. Reed was used due to its high tolerance to metals and high reproduction ability. The main metals in consideration were strontium and barium because of their extreme harmful effects to human health and the ecological environment. For instance, barium compounds can cause effects ranging from diarrhea to tachycardia to ventricular fibrillation in the animal experiments [13]. Risks of cancer increase with increased exposure to strontium [14].

\section{Methods and Materials}

The rhizomes of common reed Phragmites australis were purchased from Lorenz's OK seeds, LLC (Okeene, Oklahoma). They were initially grown in commercial potting soil (Micracle-Gro lawn products, Inc.) in pans $(45 \times 25 \times 7.5 \mathrm{~cm})$. Two $\mathrm{cm}$ of potting soil was placed in the bottom of each pan. This was followed by the rhizomes and another $2.5 \mathrm{~cm}$ of potting soil. The rhizomes were cultured in a greenhouse under natural light conditions. The average temperature of the greenhouse was $22^{\circ} \mathrm{C}$ and humidity was 50\%. Five-hundred $\mathrm{ml}$ distilled (DI) water was sprayed into each pan every day to maintain soil moisture. After 30 days of growth in the potting soil, seedlings with similar biomass were transferred into artificial solutions to initiate experiments. Prior to being transferred, the rhizomes of the reeds were rinsed with DI water to remove the attached potting soil.

Artificial hydraulic fracturing-contaminated solutions were prepared by analytical grade metal salts: barium as $\mathrm{BaCl}_{2}$ and strontium as $\mathrm{SrCl}_{2}$. Based on the typical concentration of the hydrofracturing-contaminated stream and the tolerant limits of plants, the metals concentration were $(5 \mathrm{mg} / \mathrm{L}, 20 \mathrm{mg} / \mathrm{L}$, and $80 \mathrm{mg} / \mathrm{L}$ for Ba and $5 \mathrm{mg} / \mathrm{L}$, $10 \mathrm{mg} / \mathrm{L}$, and $20 \mathrm{mg} / \mathrm{L}$ for $\mathrm{Sr}$ ) [7]. The $\mathrm{pH}$ of the solution was adjusted to 7 . In order to support the growth of reeds, nutrients were added to the solution. The main nutrients were $\mathrm{N}\left(620 \mathrm{mg} \mathrm{N} / \mathrm{L}, \mathrm{NH}_{4} \mathrm{NO}_{3}\right)$ and $\mathrm{P}$ (94 mg P/L, $\left.\mathrm{KH}_{2} \mathrm{PO}_{4}\right)$ [12].

At day 1, the solution was prepared. Then plants were transferred to the solutions and cultured in a greenhouse for one week. One reed was cultured in 1L solution that contained metals and nutrients. For each condition, three containers and reeds were used. At the end of the culturing period, reeds were harvested and then air dried. After drying, the tissues were separated into roots, rhizomes, and shoots, then weighed and crushed with mortar and pestle. The milled tissues were then digested following the methods described in Guo and Cutright [12]. Finally, the solutions were filtered by $0.45 \mu \mathrm{m}$ filters and analyzed by atomic absorption spectroscopy 6300 (AAS).

Data on metal uptake in reeds were analyzed with one-way ANOVA using the Minitab statistical package (Minitab 16). Differences between specific metal levels were identified by Tukey's test at 5\% probability.

\section{Results and Discussion}

Barium was found in the biomass of reeds cultured in solutions with different levels of metals. The translocation factors (TF) - the ratio of metal in plant shoots to that in roots - was listed in Table 1 [15]. The TF of Ba was less than 1, which also suggested that the translocation of $\mathrm{Ba}$ into the aboveground organs (shoots) of reeds was restricted. These findings were in accordance with previous studies. Ali et al. [16] indicated that large amounts of heavy metals were preferentially accumulated in the roots and rhizomes of reeds. According to Bonanno and Giudice [17], the concentration of $\mathrm{Mn}, \mathrm{Cu}$, and $\mathrm{Cr}$ in reeds grown in a wetland decreased in the order of root $>$ rhizome $>$ shoot. Baldantoni et al. [18] also found that metal levels were more than one order of magnitude lower in the shoots than those in the roots of reeds. Most of some other trace metals (e.g., Ag, Co, Be, Pd) were also accumulated in belowground organs rather than aboveground tissues of reeds [19]. However, Fawazy et al. [20] indicated that 
most $\mathrm{Cu}$ was stored in the roots while higher levels of $\mathrm{Pb}$ were found in the leaves of reeds. Similarly, according to the studies of Rzymski et al. [21], majorities of metals (e.g., Fe, Mn, Zn, Cr) were found in the roots, but higher concentrations of $\mathrm{Cd}$ and $\mathrm{Pb}$ were found in the leaves of reeds [21].

Compared to other elements, there was not much research related to $\mathrm{Ba}$ accumulation in reeds. It was reported that $\mathrm{Ba}$ was mainly stored in the roots of reeds from a mining area [22]. Bonanno [23] also indicated that the trend of Ba contents in reeds was root $>$ rhizome $>$ leaf $>$ stem. The accumulations of different metals in reeds are controlled by many factors such as specific physiological mechanisms, the concentrations and bioavailability of metals in the surrounding environment, and other physical/chemical environmental conditions [24-26]. One of the reasons that reeds can immobilize most toxic elements in the roots is to protect rhizomes, which are the only persistent part of the plant, thus less metals can be transferred from rhizomes to shoots [18]. The TF of Ba in this study was low (Table 1), which was similar to the value in the reports of $\mathrm{Li}$ et al. [22]. They found that the $\mathrm{TF}$ of $\mathrm{Ba}$ in reeds collected from uranium mill tailings was around 0.19 [22]. The low TF of Ba may be due to its low mobility as this metal was easy to be precipitated [23]. However, according to the study of Cicero-Fernández et al. [19], the TF of $\mathrm{Ba}$ in two populations of reeds transferred to the same contaminated sediment was totally different: one population initially grown in an uncontaminated area possessed a TF of 0.31 while the other, originally collected from contaminated sites, had a TF of 1.37. Guillaume et al. [27] also stated that TF can be highly different even for the same plant species. These differences of TF may reflect the fact that the mobility and translocation of metals in plants depends on such environmental factors as redox potential of soil or solution, and the concentration of a target element $[28,29]$. The plant age and ecotype may also modify the translocation of metals to plant shoot from roots [30].

More $\mathrm{Ba}$ was accumulated in the roots and rhizomes of reeds cultured in solutions with high levels of $\mathrm{Ba}$

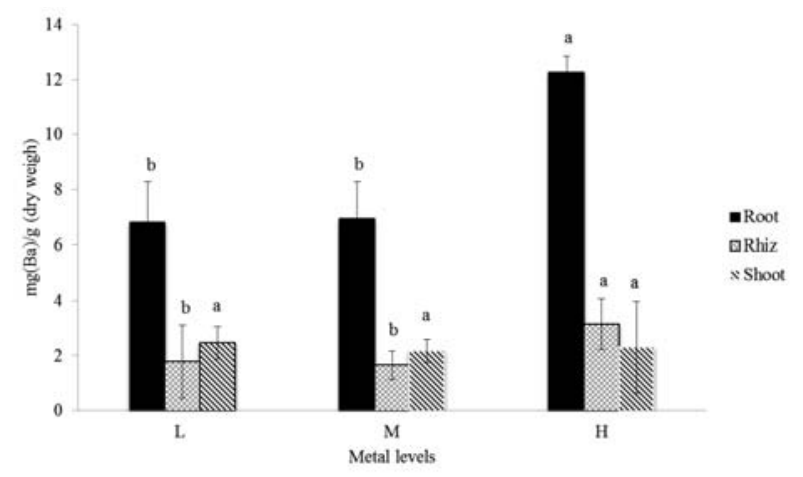

Fig. 1. Ba in the organs of reeds cultured in solution for four weeks. An error bar represented the standard deviation of triplicate samples. Different letters on the same plant organ indicated a significant difference at $\mathrm{p}<0.05$; "Rhiz" is rhizome. than those in reeds grown in solutions with low levels (Fig. 1). For instance, the roots of reeds grown in solutions with low levels of metals (LM) accumulated $6.81 \pm 1.47 \mathrm{mg} / \mathrm{g} \mathrm{Ba}$, while the roots in solutions with high level of metals (HM) sequestered $12.26 \pm 3.14 \mathrm{mg} / \mathrm{g}$ Ba after one week. This is not surprising as previous research also indicated that accumulation of metals in plants was correlated with concentrations in substrate [31]. Deng et al. [32] also stated that the concentration of metals in the underground tissues of wetland plants showed strong positive correlations with the levels of elements in sediment. Similarly, Ghassemzadehas et al. [33] also found that the uptake of metals by reeds was related to the amount of metals in the environment. However, the levels of $\mathrm{Ba}$ in the roots systems of reeds cultured in solutions with middle levels of metals (MM) was not significantly different from those in roots in LM solutions. This may be due to the fact that the Ba concentration in solutions was not high enough to affect $\mathrm{Ba}$ uptake in reeds. According to Coscione and Berton [34], the difference of Ba contents in sunflower grown in artificial Ba-contaminated soils was not significant, until up to the dose of $300 \mathrm{mg} / \mathrm{kg}$ Ba. Different from the roots, the Ba level in shoots of reeds was not affected by the concentration of $\mathrm{Ba}$ in solutions at all (Fig. 1). Similar to the findings of Junior et al. [35], the absorption of $\mathrm{Ba}$ in the aboveground tissues of sunflower plants was not affected by the increase of $\mathrm{Ba}$ doses. Plants growing in metal-enriched soils may develop some tolerance mechanisms to avoid uptaking more metals to the aboveground tissues [36]. According to the view of ecotoxicology, the limit of transferring heavy metals into shoots may help to avoid the passing of pollutants into the food chain via herbivores [19].

The accumulation of $\mathrm{Sr}$ in reeds was similar to the trends of Ba (Fig. 2). Most of $\mathrm{Sr}$ was accumulated in the roots with less $\mathrm{Sr}$ in the rhizomes and shoots of reeds. For instance, the roots of reeds grown in LM solution accumulated $1.28 \pm 0.20 \mathrm{mg} / \mathrm{g} \mathrm{Sr}$, while the shoots uptake $0.10 \pm 0.06 \mathrm{mg} / \mathrm{g} \mathrm{Sr}$ after one week. The study of Sarap et al. [37] also found that $\mathrm{Sr}$ was more concentrated in the roots of winter wheat rather than the aboveground tissues. High levels of $\mathrm{Sr}$ were also found in roots other than

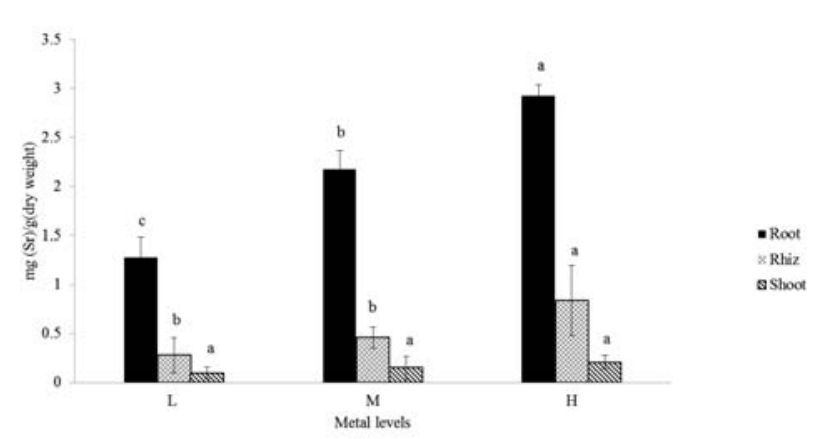

Fig. 2. Sr in the organs of reeds cultured in solution for four weeks. An error bar represents the standard deviation of triplicate samples. Different letters on the same plant organ indicate a significant difference at $\mathrm{p}<0.05$; "Rhiz" is rhizome. 
Table 1. Translocation factor of metals in reeds for four weeks.

\begin{tabular}{|c|c|c|}
\hline Treatment & TF of Ba & TF of Sr \\
\hline LM & $0.38 \pm 0.09 \mathrm{a}$ & $0.07 \pm 0.04 \mathrm{a}$ \\
\hline MM & $0.30 \pm 0.08 \mathrm{a}$ & $0.06 \pm 0.05 \mathrm{a}$ \\
\hline HM & $0.19 \pm 0.13 \mathrm{~b}$ & $0.07 \pm 0.03 \mathrm{a}$ \\
\hline
\end{tabular}

LM is low level of metals, MM is middle level of metals,

$\mathrm{HM}$ is high level of metals; results were reported as average \pm standard deviation, $\mathrm{n}=3$; different letters in the same column indicated a significant difference at $\mathrm{p}<0.05$

shoots in reeds grown in an area affected by urbanization agriculture in Italy [23]. However, a higher accumulation of $\mathrm{Sr}$ was detected in shoots rather than roots of other plants, such as sunflower [38]. These may be due to the fact that different plants had different tolerant mechanisms and uptake models to metals [39]. Other researchers also indicated that the accumulation of metals (e.g., Sr) in plants was affected by site-specific and plant-specific parameters such as the capacity of plant species, the availability of metals, and other competing elements [27, $40,41]$. For reeds, root was the main pathway for trace metals to enter tissues [42]. Thus it is not surprising that root is the main organ for storing Sr. With the increase of $\mathrm{Sr}$ in solution, more $\mathrm{Sr}$ entered roots and rhizomes. According to previous research, $\mathrm{Sr}$ concentration in the belowground organs of plants was proportional to the $\mathrm{Sr}$ level in solutions [43]. Bonanno [23] also indicated that $\mathrm{Sr}$ amounts in roots of reeds were significantly correlated with Sr levels in water.

According to Kartosentono etal. [44], the concentrations of $\mathrm{Sr}$ in shoots of Solanum laciniatum increased with the $\mathrm{Sr}$ levels in media. However, in our studies the amount of $\mathrm{Sr}$ in shoots was only slightly increased $(\mathrm{p}>0.05)$ with the increase of Sr levels in solutions, which reflected the low mobility of $\mathrm{Sr}$ in reeds. Similarly, Tsialtas et al. [40] found that the contents of $\mathrm{Sr}$ in shoots of Trifolium species were not influenced by the amounts of $\mathrm{Sr}$ in soil. Most other studies also reported the low mobility and the low translocation of $\mathrm{Sr}$ in plants $[22,45]$. The translocation of $\mathrm{Sr}$ from roots to shoots in some plants was even reduced with the increase of $\mathrm{Sr}$, which was a mechanism used to protect plants [46]. The calculated TF of Sr was very low (Table 1), which further proved that the translocation of $\mathrm{Sr}$ to shoots of reeds barely happened. Bonanno [23] also stated that the TF of $\mathrm{Sr}$ in reeds (about 0.05) was the lowest compared to other elements (e.g. Ba, Al, Fe, $\mathrm{Co}, \mathrm{V})$. Many studies found that most trace metals were stored in roots of reeds while the translocation to shoots was limited [21, 47, 48]. Thus, reeds that possess large biomass and an extensive root system are a good candidate for rhizofiltration, sequestering toxic metals from aquatic solutions with fewer contaminants remaining in the environment [49].

\section{Conclusions}

Traditional ways used to treat flowback fluids, such as centralized wastewater treatment facilities, are expensive and may not effectively remove some toxic metals. This study conducted laboratory experiments to investigate the potential of Phragmites australis to sequester $\mathrm{Ba}$ and $\mathrm{Sr}$ from flowback liquids. The results indicated that reeds have the ability to uptake $\mathrm{Ba}$ and $\mathrm{Sr}$ from flowback liquids. According to the measurement, $12.26 \pm 0.58 \mathrm{mg} / \mathrm{g}$ $\mathrm{Ba}$ and $2.92 \pm 0.12 \mathrm{mg} / \mathrm{g}$ Sr were sequestered in roots from solutions that contained $80 \mathrm{mg} / \mathrm{L} \mathrm{Ba}$ and $20 \mathrm{mg} / \mathrm{L} \mathrm{Sr}$. The more metals in solutions, the more metals entered biomass.

Phragmites australis is known to be widely distributed in the world, survive in both terrestrial and hydroponic habitats, and possesses high adaptability to different conditions is a good candidate for phytoremediation technique to clean heavy metal-contaminated water or soil. Underground tissues were the main tissues for metal storage in reeds. Chelator may be used to increase metal accumulation and metal translocation to aboveground organs. Studies on the interactions between rhizosphere microorganisms and plants may be conducted to find the ways to enhance plant growth and increase the efficiency of phytoremediation. More research on the physiology alternation in reeds caused by heavy metals is recommended. Further studies on the metal accumulation in reeds cultured in real flowback liquids are also needed. This will assist with any further research on in-situ remediation of heavy metal-contaminated sites.

\section{Acknowledgements}

Our work was supported by a Faculty Research Enhancement Grant from the Office of Research and Sponsored Programs at Texas A\&M UniversityCommerce.

\section{References}

1. VENGOSH A., JACKSON R.B., WARNER N., DARRAH T.H., KONDASH A. A critical review of the risks to water resources from unconventional shale gas development and hydraulic fracturing in the United States. Environ. Sci. Technol. 48, 8334, 2014.

2. ENVIRONMENTAL PROTECTION AGENCY (EPA). Assessment of the potential impacts of hydraulic fracturing for oil and gas on drinking water resources EPA/600/R15/047a, 2015.

3. BURTON G.A., BASU N., ELLIS R., KAPO K.E., ENTREKIN S., NASWLHOFFER K. Hydraulic «Fracking»: are surface water impacts an ecological concern? Environ. Toxicol. Chem. 33, 1679, 2014.

4. BALABA R.S., SMART R.B. Total arsenic and selenium analysis in Marcellus shale, high-salinity water, and hydrofracture flowback wastewater. Chemosphere 89, 1437, 2012. 
5. CHAPMAN E.C., CAPO R.C., STEWART B.W., KIRBY C.S., HAMMACK R.W., SCHROEDER K.T., EDENBORN H.M. Geochemical and strontium isotope characterization of produced waters from marcellus shale natural gas extraction. Environ. Sci. Technol. 46, 3545, 2012.

6. CLARK C.E., VEIL J.A. Produced water volumes and management practices in the United States (ANL/ EVS/R-09/1). Argonne IL, Argonne National Laboratory, 2009.

7. FERRAR K.J., MICHANOWICZ D.R., CHRISTEN C.L., MULCAHY N., MALONE, S.L., SHARMA R.K. Assessment of effluent contaminants from three facilities discharging marcellus shale wastewater to surface waters in Pennsylvania. Environ. Sci. Technol. 47, 3472, 2013.

8. GHOSH S., MOITRA M., WOOLVERTON C.J., LEFF L.G. Effects of remediation on the bacterial community of an acid mine drainage impacted stream. Can. J. Microbiol. 58, 1316, 2012.

9. GHOSH M., SINGH S.P. A review on phytoremediation of heavy metals and utilization of its byproducts. Appl. Ecol. Environ. Res. 3, 1, 2005.

10. STOLTZ E., GREGER M. Influences of wetland plants on weathered acidic mine tailings. Environ. Pollut.144, 689, 2006.

11. BATTY L.C., YOUNGER P.L. Growth of Phragmites australis (Cav.) Trin ex. Steudel in mine water treatment wetlands: effects of metal and nutrient uptake. Environ. Pollut. 132, 85, 2004.

12. GUO L., CUTRIGHT T.J. Effect of citric acid and bacteria on metal uptake in reeds grown in a synthetic acid mine drainage solution. J. Environ. Manage. 150, 235, 2015.

13. THEEGALA C.S., ROBERTSON C.E.C., SULEIMAN A.A. Phytoremdiation potential and toxicity of barium to three freshwater microalgae: Scenedesmus subspicatus, Selenastrum capricorntum, and Nannochloropsis sp. Pract. Period. Hazard. Toxic. Radioact. Waste Manag. 5, 194, 2001.

14. SASMAZ A., SASMAZ M. The phytoremediation potential for strontium of indigenous plants growing in a mining area. Environmen. Exper. Bot. 67, 139, 2009.

15. MARQUES A.P.G.C., OLIVEIRA R.S., SAMARDJIEVA K.A., PISSARRA J., RANGEL A.O.S.S., CASTRO P.M.L. EDDS and EDTA-enhanced zinc accumulation by Solanum nigrum inoculated with arbuscular mycorrhizal fungi grown in contaminated soil. Chemosphere, 70, 1002, 2007.

16. ALI N.A., BERNAL M..P, ATER M. Tolerance and bioaccumulation of copper in Phragmites australis and Zea mays. Plant Soil 239, 103, 2002.

17. BONANNO G., GIUDICE R. Lo. Heavy metal bioaccumulation by the organs of Pharamites australis (common reed) and their potential use as contamination indicators. Ecol. Indic. 10, 39, 2010.

18. BALDANTONI D., LIGRONE R., ALFANI A. Macroand trace-element concentrations in leaves and roots of Phragmites australis in a volcanic lake in Southern Italy. J. Geochem. Explor. 101,166, 2009.

19. CICERO-FERNÁNDEZ D., PEÑA-FERNÁNDEZ M., EXPÓSITO-CAMARGO J.A., ANTIZAR-LADISLAO B. Role of Phragmites australis (common reed) for heavy metals phytoremediation of estuarine sediments. Int $\mathrm{J}$ Phytorem. 18 (6), 575, 2016.

20. FAWAZY M.A., BADR NE-S., ABO-El-KASSEMA. Heavy metal biomonitoring and phytoremediation potentialities of aquatic macrophytes in River Nile. Environ. Monit. Assess. 184, 1753, 2012.
21. RZYMSKI P, NIEDZIELSKI P, KLIMASZYK P, PONIEDZIALE B. Bioaccumulation of selected metals in bivalves (Vnionidae) and Phragmites australis inhabiting a municipal water reservoir. Environ. Monit. Assess. 186 (5), 3199, 2014.

22. LI G., HU N., DINGD., ZHENG J., LIU Y., WANG Y., NIE X. Screening of plant species for phytoremediation of uranium, thorium, barium, nickel, strontium and lead contaminated soils from a uranium mill tailings repository in south China. Bull. Environ. Contam. Toxicol. 86, 646, 2011.

23. BONANNO G. Trace element accumulation and distribution in the organs of Phragmites australis (common reed) and biomonitoring applications. Ecotoxicol Environ Saf. 74 (4), 105764, 2011.

24. HAMIDIAN A.H., ZAREH M., POORBAGHER, H., VAZIRI L., ASHRAFI S. Heavy metal bioaccumulation in sediment, common reed, algae, and blood worm from the Shoor river, Iran. TToxicol. Ind. Health 32, 398, 2016.

25. ZHANG H.G., CUI B.S., ZHANG K.J. Heavy metals distribution of natural and reclaimed tidal riparian wetlands in south estuary, China. J. Environ. Sci. 23, 1937, 2011.

26. GUO L., CUTRIGHT T. J. Metal storage in reeds from an acid mine drainage contaminated field. Int. J. Phytorem. 19, 254, 2017.

27. GUILLAUME T., CHAWLA F., STEINMANN P., GOBAT J., FROIDEVAUX P. Disparity in $90 \mathrm{Sr}$ and $137 \mathrm{Cs}$ uptake in Alpine plants: phylogenetic effect and $\mathrm{Ca}$ and $\mathrm{K}$ availability. Plant Soil, 355, 29, 2012.

28. YE Z.H., WONG M.H., BAKER A.J.M., WILLIS A.J. Comparison of biomass and metal uptake between two populations of Phragmites australis grown in flooded and dry conditions. Ann. Bot. 82, 83, 1998.

29. STOLTZ E., GREGER M. Effects of different wetland plant species on fresh unweathered sulphidic mine tailings. Plant Soil 276, 251, 2005.

30. YANG J., YE Z. Metal accumulation and tolerance in wetland plants. Front. Biol. China. 4, 282, 2009.

31. TAYLOR G.J., CROWDER A.A., RODDEN R. Formation and Morphology of an Iron Plaque on the Roots of Typha latifolia L. Grown in Solution Culture. Amer. J. Bot .71, 666, 1984.

32. DENG H., YE Z.H., WONG M.H. Accumulation of lead, zinc, copper and cadmium by 12 wetland plant species thriving in metal-contaminated sites in China. Environ. Pollut. 132, 29, 2004.

33. GHASSEMZADEH, F., YOUSEFZADEH, H., ARBABZAVAR, M.H. Arsenic phytoremediation by Phragmites australis: green technology. Int. J. Environ. Stud. 65, 587, 2008.

34. COSCIONE A.R., BERTON R.S. Barium extraction potential by mustard, sunflower and castor bean. Scientia. Agricola. 66, 59, 2009.

35. JUNIOR J.M., SOBRINHO N.M.D., BO A., ZONTA E., MAGALHÃES, M.O.L. Barium and sodium in sunflower plants cultivated in soil treated with wastes of drilling of oil well. Rev. Bras. Eng. Agríc. Ambient. 19, 1100, 2015.

36. ERNST W.H.O. Evolution of metal tolerance in higher plants. For Snow Landsc. Res. 80, 251, 2006.

37. SARAP, N., JANKOVIĆ, M., DOLIJANOVIĆ, Ž., KOVAČEVIĆ, D., RAJAČIĆ, M., NIKOLIĆ, J., TODOROVIĆ, D. Soil-to-plant transfer factor for $\mathrm{Sr}$ and Cs. J. Radioanal. Nucl. Chem. 303, 2523, 2015.

38. SOUDEK P., VALENOVÁ Š., VAVŘ́IIKOVÁ Z., VANĚK T. ${ }^{137} \mathrm{Cs}$ and ${ }^{90} \mathrm{Sr}$ uptake by sunflower cultivated under hydroponic conditions. J. Environ. Radioactiv. 88, 236, 2006. 
39. TAYLOR, G.J., CROWDER A.A. Uptake and accumulation of heavy metals by Typha latifolia in wetlands of the Sudbury, Ontario region. Can. J. Bot. 61, 63, 1983.

40. TSIALTAS, J. T., MATSI, T., BARBAYIANNIS, N., SDRAKAS, A., VERESOGLOU, D.S. Strontium absorption by two trifolium species as influenced by soil characteristics and liming. Water Air Soil Pollut. 144, 363, 2003.

41. SANCHEZ A.L., SMOLDERS E., VAN DEN BRANDE K., MERCKX R., WRIGHT S.M., NAYLOR C. Predictions of in situ solid/liquid distribution of radiocaesium in soils. J. Environ. Radioact. 63, 35, 2002.

42. KUMAR, J.I.N., SONI, H., KUMAR, R.N. Biomonitoring of selected freshwater macrophytes to assess lake trace element contamination: a case study of Nal Sarovar Bird Sanctuary, Gujarat. India. J. Limnol. 65, 9, 2006.

43. REDISKE J.H., SELDERS A.A. The absorption and translocation of strontium by plants. Plant Physiol. 28, 594, 1953.

44. KARTOSENTONO, S., ZAINI, N., I NDRYANTO, G., NURAIDA, A. Phytoremediation of $\mathrm{Sr}^{2+}$ and its influence on the growth, $\mathrm{Ca}^{2+}$ and solasodine content of shoot cultures of Solanum laciniatum. Biotechnol Lett, 23, 153, 2001.
45. VANDECASTEELE, B., QUATAERT, P., TACK, F.M.G. The effect of hydrological regime on the metal availability for the wetland plant species Salix cinerea. Environ. Pollut. 135, 303, 2005.

46. MOYEN C., ROBLIN, G. Uptake and translocation of strontium in hydroponically grown maize plants, and subsequent effects on tissue ion content, growth and chlorophyll a/b ratio: comparison with $\mathrm{Ca}$ effects. Environmen. Exper. Bot. 68, 247, 2010.

47. HECHMIN N, BEN AISSA N., ABDENACEUR H., JEDIDI N. Uptake and bioaccumulation of pentachlorophenol by emergent wetland plant Phragmites australis (Common Reed) in Cadmium co-contaminated soil. Int. J. Phytorem. 17 (2), 109, 2015.

48. PHILLIPS D.P., HUMAN L.R.D., ADAMS J.B. Wetland plants as indicators of heavy metal contamination. Mar. Pollut. Bull. 92, 227, 2015.

49. KYOKO H., MASATAKE K., MASAHISA T., HARUKA I., NAOFUMI S., NAOKO F., YASUNORI N., NOBUO S., SHU F, EITARO M. Common reed accumulates starch in its stem by metabolic adaptation under Cd stress conditions. Front. Plant. Sci. 6, 138, 2015. 